\title{
Literatura v preseku družbe, družba v preseku literature The Crossroads of Literature and Social Praxis
}

\author{
Uredil
}

Marcello Potocco 
Uredniški odbor Založbe Univerze na Primorskem

Gregor Pobežin, UP Fakulteta za humanistične študije Maja Meško, UP Fakulteta za management

Vito Vitrih, UP FAMNIT in UP IAM

Silva Bratož, UP Pedagoška fakulteta

Aleksandra Brezovec, UP FTŠ - Turistica

Ana Petelin, UP Fakulteta $z a$ vede o $z$ dravstvu

Janko Gravner, University of California, Davis

Krstivoje Špijunović, Učiteljski fakultet Užice

Miloš Zelenka, Jihočeská univerzita v Českých Budějovicích

in Univerzita Konštantína Filozofa $v$ Nitre

Jonatan Vinkler, Založba Univerze na Primorskem

Alen Ježovnik, Založba Univerze na Primorskem 
literatura v preseku družbe, družba v preseku literature the crossroads of literature and social praxis 



\section{Literatura v preseku družbe, družba v preseku literature}

The Crossroads of Literature and Social Praxis

16. mednarodni komparativistični kolokvij

$16^{\text {th }}$ International Comparative Literature Colloquium

Zbornik povzetkov - Book of Abstracts

Uredil - Edited by Marcello Potocco 
Literatura v preseku družbe, družba v preseku literature:

zbornik povzetkov, Ljubljana, 5. in 6. september 2018

The Crossroads of Literature and Social Praxis:

Book of Abstracts, Ljubljana, 5-6 September 2018

16. mednarodni komparativistični kolokvij

$16^{\text {th }}$ International Comparative Literature Colloquium

Organizatorji • Organizers:

Mednarodni literarni festival Vilenica, Slovensko društvo za primerjalno književnost, Fakulteta za humanistične študije Univerze na Primorskem International Literary Festival Vilenica, Slovenian Comparative Literature Association, Faculty of Humanities, University of Primorska

Uredil - Edited by Marcello Potocco

Prevod in lektura (ang.) - Translation and proofreading - Barbara Jurša Lektura (slo.) • Proofreading - Ana Beguš

Oblikovanje in prelom - Design and Typesetting - Jonatan Vinkler

Izdala . Published by - Založba Univerze na Primorskem

University of Primorska Press,

Titov trg 4, sl-6000 Koper,

Koper 2018

Glavni urednik • Editor-in-Chief • Jonatan Vinkler

Vodja založbe $\cdot$ Managing Editor • Alen Ježovnik

ISBN 978-961-7055-16-o (www.hippocampus.si//SBN/978-961-7055-16-o.pdf)

ISBN 978-961-7055-17-7 (www.hippocampus.si/lSBN/978-961-7055-17-7/index.html)

DOI: https://doi.org/10.26493/978-961-7055-16-0

(c) 2018 Založba Univerze na Primorskem • University of Primorska Press

\section{(c) (1) $\Theta$}

Kataložni zapis o publikaciji (CIP) pripravili v Narodni in univerzitetni knjižnici v Ljubljani COBISS.SI-ID $=296215808$ 


\section{vsebina \\ contents}

7 O KONFERENCI = CONFERENCE DETAILS

11 PROGRAM KONFERENCE — CONFERENCE PROGRAMME

15 POVZETKI = ABSTRACTS

51 UDELEŽENCI * PARTICIPANTS 

o konferenci

conference details 
impozij Literatura v preseku družbe, družba v preseku literature se bo ukvarjala $z$ obravnavo razmerja med literaturo (ter umetnostjo na sploh) in njenim družbenim kontekstom, namerava torej odpreti vprašanje njune medsebojne interakcije. $\mathrm{Na}$ eni strani se bo odpiralo vprašanje, kako književnost in umetnost sodelujeta pri opomenjanju družbene sfere, na drugi strani pa, kako družbeni akterji uporabljajo (in zlorabljajo) književne prakse za ustvarjanje specifičnih pomenov - in specifičnih ideoloških narativ -, ki jih želijo reproducirati v nekem družbenem kontekstu. Najkasneje od raziskav t.i. althusserjancev (zlasti P. Machereyja in E. Balibarja) ter teorij diskurza (najpoprej seveda pri M. Foucaultu) naprej je jasno, da književnosti ne smemo razumeti kot od družbene prakse avtonomne prakse, marveč ravno nasprotno kot del diskurzivnih formacij, $v$ katerih centri moči proizvajajo in reproducirajo pomene, tudi če prikrito in uporabljajoč ideologijo avtonomnosti. Z nekoliko drugačne perspektive so se teh procesov lotili kulturni študiji in Stuart Hall, ki tudi književnost razume kot del t.i. kulturnega kroženja, $v$ katerem se nenehno prepletajo posameznikova in/ali družbena identiteta, produkcija kulturnih proizvodov, njihova potrošnja, regulacija in reprezentacija, tj. diskurzivni proces, v okviru katerega se tvorijo družbeni pomeni.

Simpozij Literatura v preseku družbe, družba v preseku literature se sicer ne bo povsem izogibal teoretski refleksiji zgornjih vprašanj; ta je bila $v$ zadnjih štirih zelo plodovita, raznolika, na določenih mestih pa tudi izčrpana. Prav zato se bo simpozij bolj osredinil na konkretne primere literarnega in družbenega opomenjanja, tako splošnejše (npr. primeri nacionalne ideologije) kot specifičnejše $-v$ center pozornosti simpozij namreč želi postaviti obdobje po drugi svetovni vojni in delovanje diskurzivnih formacij na obeh straneh povojne blokovske delitve, tj. vzhodne komunistične in socialistične ter zahodne kapitalistične, in ju primerjati, tudi s stališča prikritega ali odkritega ideološkega delovanja $v$ enem ali $v$ drugem. 
T he symposium The Crossroads of Literature and Social Praxis will be devoted to the research on the interaction of literature and its social context. On the one hand this opens the question of how literature and art take part in the circulation of significations and representations in the construction of social reality. On the other hand the path is opened to the research on how actants in a given society use (and abuse) literary praxis in the creation of specific significations, as well as research on the ideological narratives that are reproduced in society. With the Althusserian school at the latest, as well as the theory of discourse, it became clear that literature should not necessarily be understood as an autonomous social praxis. On the contrary, it may be interpreted as a praxis operating within discursive formations, where significations are (re)produced, even in the manner of using the ideology of autonomy. In cultural studies, literature is likewise regarded as a praxis in the circuit of culture which operates as an intersection of identity, production and consumption of cultural products, their regulation and representation; it therefore also operates as a discursive process (re)producing social meanings.

The symposium The Crossroads of Literature and Social Praxis will not altogether ignore the theoretical observation of these problems; in the past five decades, the research on these issues has been very fruitful and diverse, and to some extent exhausted. This is why we would like our symposium to focus on case studies revealing the mechanisms of literary and social representations both in a more general context (e.g. cases of national ideology) as well as within specific social contexts. The symposium would like to shed some light on the period after World War 2, especially on the operation of discursive formations in countries of both the Eastern and the Western Bloc, i.e. the eastern communist and the western capitalist countries; these can also be compared with regard to the open and/or latent (hidden) ideological interpelation in their societies. 

program konference conference programme 


\section{5. september 2018}

9.00-9.15 Pozdravni nagovori

9.15-9.30 Uvod v kolokvij (Marcello Potocco)

9.30-11.15 1. sklop:

Jonatan Vinkler, Janez Strehovec

\section{Odmor za kavo}

11.40-13.10 2. sklop:

Valter Milovan, Roland Orczik, Maka Elbakidze

\subsection{Kosilo}

15.00-16.30 3. sklop: Stephan Baghiu, Andrei Terian, Irma Ratiani

\section{Odmor za kavo}

16.45-18.15 $\quad \begin{aligned} & \text { 4. sklop: } \\ & \text { Gaga Lomidze, Varja Balžalorsky Antić, Ana Beguš }\end{aligned}$

\section{6. september 2018}

\begin{tabular}{cl}
\hline $9.15-10.45$ & $\begin{array}{l}\text { 5. sklop: } \\
\text { Tomaž Toporišič, Gašper Troha, Maja Murnik }\end{array}$ \\
\hline $11.00-12.30$ & $\begin{array}{l}\text { Literarno branje in pogovor: } \\
\text { Malta na Vilenici (Klub Cankarjevega doma) }\end{array}$ \\
& Odmor za kavo \\
& $\begin{array}{l}\text { 6. sklop: } \\
\text { Marcello Potocco, Špela Virant, Aleš Kozar }\end{array}$ \\
\hline $14.50-14.20-145$ & Splošna razprava \\
15.00 & Kosilo \\
\hline
\end{tabular}




\section{September $5^{\text {th }}$}

\begin{tabular}{|c|c|}
\hline $9.00-9.15$ & $\begin{array}{l}\text { Speeches } \\
\text { (President of the SiCLA, Organising Committee) }\end{array}$ \\
\hline $9.15-9.30$ & Introduction (Marcello Potocco) \\
\hline \multirow[t]{2}{*}{$9.30-11.15$} & $\begin{array}{l}\text { Session 1: } \\
\text { Jonatan Vinkler, Janez Strehovec }\end{array}$ \\
\hline & Coffee break \\
\hline $11.40-13.10$ & $\begin{array}{l}\text { Session 2: } \\
\text { Valter Milovan, Roland Orczik, Maka Elbakidze }\end{array}$ \\
\hline 13. 30 & Lunch \\
\hline \multirow[t]{2}{*}{$15.00-16.30$} & $\begin{array}{l}\text { Session 3: } \\
\text { Stephan Baghiu, Andrei Terian, Irma Ratiani }\end{array}$ \\
\hline & Coffee break \\
\hline $16.45^{-18.15}$ & $\begin{array}{l}\text { Session 4: } \\
\text { Gaga Lomidze, Varja Balžalorsky Antić, Ana Beguš }\end{array}$ \\
\hline \multicolumn{2}{|c|}{ September 6th } \\
\hline $9.15-10.45$ & $\begin{array}{l}\text { Session 5: } \\
\text { Tomaž Toporišič, Gašper Troha, Maja Murnik }\end{array}$ \\
\hline \multirow[t]{2}{*}{$11.00-12.30$} & $\begin{array}{l}\text { Literary reading: } \\
\text { Literature of Malta (Cankarjev dom) }\end{array}$ \\
\hline & Coffee break \\
\hline $12.50-14.20$ & $\begin{array}{l}\text { Session 6: } \\
\text { Marcello Potocco, Špela Virant, Aleš Kozar }\end{array}$ \\
\hline $14.20-14.45$ & General discussion \\
\hline 15.00 & Lunch \\
\hline
\end{tabular}





\section{povzetki abstracts}


Ştefan Baghiu

Univerza Luciana Blage v Sibiuju

Funkcije socialističnega realizma: podzvrsti prevodne literature v povojni vzhodni Evropi

Kot glavno razliko med socialističnim realizmom in zahodnim lepd oslovjem pogosto razumemo stopnjo literarnosti (estetski napor $v$ nasprotju z družbenim namenom) obeh modelov leposlovja: kot trdi Boris Groys, je »osrednja opozicija, ki je na delu v modernizmu, med visoko kulturo ter množično (ali 'nizko') kulturo« (A Style and a Half. Socialist Realism between Modernism and Postmodernism, Dobrenko, Lausen, 1997). Tako je bil socialistični realizem vselej proglaševan za gibanje množične kulture, a je le malo študijam uspelo opredeliti njegovo pravo strukturo kot takšno, ki bi naslavljala množice. Prispevek bo preučil zvrsti in podzvrsti socialističnorealističnega leposlovja, ki je bilo prevedeno v Romuniji (kvantitativni pristop) in vzhodni Evropi (s pomočjo beril oziroma zbornikov socialističnega realizma), s ciljem pridobiti celovitejši vpogled $v$ družbeni namen in funkcije literature socialističnega realizma (saj je, po besedah Itamarja Even-Zoharja, prevodna literatura »najaktivnejši sistem znotraj polisistema« - Polysystem Studies, 1990). Kot ugotavlja Gleb Tsipursky, so boljševiki »po oktobrski revoluciji naredili državno sponzorirano popularno kulturo za glavno sfero dejavnosti sovjetske partije-države« (Socialist Fun, 2016). To je pripeljalo do mnogih poskusov nadzora nad popularnimi in mladinskimi romani kot osrednjim delom ideološkega programa znotraj same ZSSR kot tudi na celotnem območju njenega vpliva. Hkrati lahko to prizadevanje primerjamo z razvojem popularnega leposlovja $v$ zahodnih kulturah, saj si ta nasprotujoča si kulturna sistema delita več medsebojnih podobnosti: če upoštevamo, da so bili najbolj prevajani leposlovni avtorji v stalinističnem romunskem kulturnem sistemu Alexandre Dumas, Jack London ali Mark Twain, se zev med zahodno in vzhodno popularno literaturo ne more več zdeti tako velika. Prispevek želi s tehnikami oddaljenega branja ( $v$ glavnem grafi in zemljevidi) opisati in pojasniti načine uvažanja popularne literature $\checkmark$ socialistični realizem $\vee$ Romuniji in vzhodni Evropi ter načine, na katere je popularna literatura modificirala medvojni kulturni sistem oziroma se povezovala z zahodnimi kulturnimi sistemi. 
Ştefan Baghiu

Lucian Blaga University of Sibiu

The Functions of Socialist Realism:

Subgenres of Translated Fiction in Postwar Eastern Europe

The main difference between socialist realism and Western fiction is often considered to be the degree of literariness (aesthetic labor vs. social purpose) of the two models of fiction: as Boris Groys puts it, "the central opposition operative in modernism was therefore high culture versus mass (or 'low') culture" (A Style and a Half. Socialist Realism between Modernism and Postmodernism, Dobrenko, Lausen, 1997). Socialist realism has always been declared a mass culture movement, but few studies have succeeded in defining its true structure as being mass-addressed. This paper aims to analyze the genres and subgenres of socialist realist fiction translated in Romania (quantitative approach) and Eastern Europe (using general readers for socialist realism fiction) with a view to acquiring a more comprehensive perspective of the social purpose and functions of socialist realist literature (since, as Itamar Even-Zohar argues, translated literature is "a most active system within" a polysystem - Polysystem Studies, 1990). As Gleb Tsipursky remarks, "after the October Revolution, the Bolsheviks made state-sponsored popular culture a major sphere of activity for the Soviet party-state" (Socialist Fun, 2016). This led to many attempts at controlling popular and youth novels as central part of the ideological program within the USSR and also in its entire sphere of influence. At the same time, this struggle should be opposed/connected to the development of popular fiction in Western cultures, as the two opposite cultural systems shared several important similarities: if we consider that the most translated authors of fiction in the Stalinist Romanian cultural system were Alexandre Dumas, Jack London or Mark Twain, the gap between Western and Eastern popular fiction no longer seems so great. This paper uses Distant Reading techniques (mainly graphs and maps) to describe and explain the ways in which popular fiction was imported in the Socialist Realism in Romania and Eastern Europe and how it modified the interwar cultural system/how it related to Western cultural systems. 
Varja Balžalorsky Antić

Univerza v Ljubljani

\section{Ženski pesemski diskurzi znotraj spleta povojnih ideologij: nekaj vidikov}

Prispevek bo skušal razgrniti nekatere vidike zoperstavljanja različnim ideologemom, ki so se vzpostavili v družbeno-političnem in kulturno-literarnem sistemu ter literarnem diskurzu $\vee$ prvih desetletjih po drugi svetovni vojni, in sicer pri nekaterih ženskih pesnicah. Soodnosnost in tenzijo med ideologijo in poezijo bom najprej obravnavala $s$ perspektive vzpostavljanja novih pesniških paradigem in ideološko-estetičnega odziva nanje na primeru zbirke Senca v srcu Ade Škerl, ki je bila objavljena $v$ času razmaha t. i. graditeljske poezije kot ideološko predpisane poetološke norme. Kot dejanska utemeljiteljica t. i. pesniškega intimizma, povsem nasprotnega slavilni poeziji, ta zbirka ni bila le spregledana, temveč, kot je razvidno iz tedanjih burnih kritiških odzivov, obsojena na marginalizacijo in celo izobčenje, do prave rekanonizacije pesnice pa je prišlo šele na začetku naslednjega tisočletja. $\mathrm{Na}$ veliko bolj odobravajoče odzive sta naleteli zbirki Mesečev konj in Naplavljeni plen Saše Vegri, ki je najbolj izpostavljena oziroma (po literarnozgodovinskih kategorizacijah) edina ženska predstavnica prvega vala t. i. kritične generacije. Pri slednji dobi tenzija med vladajočo ideologijo in novo uveljavljujočo se paradigmo modernizma ostrejše tone, pesniški glas Vegrijeve iz njenih prvih dveh zbirk pa s tega aspekta kaže nekatere posebnosti $\vee$ primerjavi z drugimi osrednjimi zbirkami (moških avtorjev), ki so zaznamovale nastop kritične generacije. $\mathrm{Na}$ »drugačnost« tega pesniškega glasu je opozorila že tedanja literarna kritika, ki v nasprotju s primerom Škerlove sicer ni bila odklonilna, vendar je, kot se pokaže, ostala močno zakoreninjena $v$ patriarhalnem kritiškem diskurzu. Zadnji vidik, ki ga želim načeti v tem prispevku, je vprašanje ideologije materinstva. Iz gradiva, ki ga ponujajo javna občila, ki so obravnavala žensko problematiko po koncu druge svetovne vojne, zlasti glasilo Naša žena, je razvidno, da je ideologija »materinjenja« kot najbolj določujočega elementa ženskosti po kratkem medvojnem zatišju ponovno vstopila na velika vrata tudi v novo socialistično družbo. $\vee$ prispevku bom kratko izpostavila reprezentacije materinstva $v$ nekaterih zbirkah Saše Vegri in Svetlane Makarović, ki bolj ali manj radikalno, od »znotraj« ali od »zunaj« dekonstruirajo »materinski mit«. 
Varja Balžalorsky Antić

University of Ljubljana

\section{Women's Poetic Discourses in the Web of Postwar Ideologies: Some Aspects}

The paper will attempt to unveil some aspects of resisting various ideologemes established in the socio-political and cultural literary system as well as literary discourse of the first decades after World War II that can be found in the work of some women poets. The interdependence and tension between ideology and poetry will first be addressed from the perspective of setting up new poetic paradigms and the ideological-aesthetic response towards them by looking at the poetry collection Senca $v$ srcu (Shadow in the Heart) by Ada Škerl, which was published at the time of the prospering »(political) construction poetry« as an ideologically prescribed poetological norm. As an actual founder of the so-called poetic intimism, which contrasted with the prevailing praise poetry, this book was not only ignored, but also, as can be seen from the then heated critical responses, denounced and destined for marginalization or even ostracism; the recanonization of the poet had to wait until the beginning of the next millenium. The poetry collections Mesečev konj (The Moon Horse) and Naplavljeni plen (The Beach-deposited Booty) by Saša Vegri received a lot more critical approval. Vegri was the most visible or (according to literary-historical categorizations) the only female representative of the first wave of the so called »critical generation«. The work by this generation of writers is distinguished by the tension between the ruling ideology and the new, upcoming paradigm of modernism associated with sharper tones. With regard to this aspect, Vegri's poetic voice in her first two books stands out as distinctly different from the other seminal poetry collections (by male authors) that marked the emergence of »the critical generation«. The then literary criticism recognised that this voice was somehow »peculiar« but did not show an unfavourable reaction towards it, as was the case with Škerl; nonetheless, it remained deeply rooted in the patriarchal critical discourse. The last aspect that I want to tackle is the ideology of motherhood. The evidence provided by the public media that focused on »the women's problematics « after the end of World War 2, especially the women's magazine Naša žena (Our woman), reveals that the ideology of »mothering « as the most defining element of femininity - following a short break between the Wars - re-entered the stage in the new, socialist society. I will briefly deal with the representations of motherhood in some texts by Saša Vegri and Svetlana Makarović, who radically deconstruct the myth of motherhood either from »within« or »without«. 
Ana Beguš

Univerza na Primorskem

\section{Tehnološka remediacija žanrov in literatura}

$\checkmark$ prispevku povezujem pojme žanra, tehnologije in remediacije, pri čemer izpostavljam tehnološki vpliv na žanr in diskurz. Ta je v jezikoslovnem, literarnem in kulturološkem raziskovanju večinoma spregledan, saj se analiza osredotoča predvsem na diskurzivno interpretacijo vsebine, zapostavlja pa strukturno pristranskost tehnološkega vmesnika, ki se ga uporabnik zaradi njegove privzetosti ne zaveda. Nova tehnologija je proces, ki ustvarja novo okolje in skozi proces remediacije preoblikuje obstoječe ter generira nove žanre. Tehnološko okolje torej lahko razumemo kot posebno raven konteksta med besedilnim (ko-tekstom) in družbenim (kontekstom), ki ga lahko materialno analiziramo. $\vee$ članku pojem remediacije obravnavam na primeru imaginativnega diskurza (literature, filma in AV medijev, glasbe) in v glavnih črtah orišem današnji tehnološki ekosistem ter žanrska razmerja $v$ njem, pri čemer podrobneje analiziram vaporwave kot eksemplaričen primer novega žanra. 
Ana Beguš

University of Primorska

Technological Remediation of Genres and Literature

In this paper, I connect the concepts of genre, technology and remediation, while emphasizing the influence of technology on genre and discourse. This influence has been to a great extent neglected in linguistic, literary and cultural research, since the analysis focuses mainly on the discursive interpretation of content while ignoring the structural bias of the technological interface; the user is normally not aware of this bias as it is taken for granted. New technology is creating a new environment and through the process of remediation it is transforming the existing genres and generating new ones. The technological environment can thus be understood as a special level of context between the textual (co-text) and the social (context), which can be subject to material analysis. In my paper, I tackle the concept of remediation by looking at the example of imaginative discourse (literature, film and AV media, music), and I delineate, in rough outlines, the technological ecosystem and its internal genre relationships, while analyzing in more detail vaporwave as an exemplary case of a new genre. 


\section{Maka Elbakidze}

Državna univerza Ivaneja Javakhishvilija v Tbilisiju

\section{Prepovedana domovina: znanstveno delovanje Victorja Nozadzeja s stališča sovjetske ideologije}

»Vsak Gruzijec v tujini je predstavnik svojega naroda« - te besede je zapisal izseljeni gruzijski pisec in raziskovalec Viktor Nozadze, ki je bil obsojen na izgnanstvo ter nenehno nomadstvo. Čas njegove ustvarjalne zrelosti je sovpadel z obdobjem, ko je nova Gruzija, ki se je od leta 1921 imenovala »komunistična«, prepovedovala delovanje vsem, ki si politične prihodnosti države niso znali zamišljati v rdečih barvah. Pot, ki je zaznamovala njegovo dramatično življenje, pokriva široko geografsko področje - Francijo, Nemčijo, Avstrijo, Argentino, Čile, Brazilijo, Španijo in nazadnje spet Francijo ... Med tem tridesetletnim »tavanjem« je ustvaril šest monumentalnih del, posvečenih glavnim problemom Rustavelijevega epa Vepkhistqaosani (»Vitez v panterjevi koži«) - povsem sam, brez finančne podpore, zahvaljujoč svojemu velikanskemu talentu in volji.

Preučevanje epa Vepkhistqaosani - ali, z Nozadzejevimi besedami, »iskanje« - se je pričelo ob koncu druge svetovne vojne, v berlinskem obdobju njegovega življenja. Njegov cilj je bil vključiti raziskovalno problematiko tega epa $\vee$ kulturni sistem s preučevanjem Rustavelijevega svetovnega nazora oziroma njegove povezanosti s svetovno kulturo, s čimer je prihodnjim generacijam raziskovalcev olajšal umeščanje gruzijske književnosti $v$ kontekst svetovne civilizacije. Nozadze je pravilno ugotavljal, da gruzijski narod znotraj razvoja svetovne kulture ne more predstavljati ponudnika, ampak prej sprejemnika. Sprejemanje kulture, njeno procesiranje $v$ lastni narodni zavesti ter njeno presajanje na domača tla niso značilni za vse narode. In če se je gruzijski narod znotraj svetovne kulture znašel $\checkmark$ položaju sledilca, kjer je ostal še danes, lahko po Nozadzejevem mnenju to razumemo kot rezultat njegovega nacionalnega talenta.

Namen prispevka je prikazati delovanje ideološkega mehanizma, zaradi katerega je do konca petdesetih let prejšnjega stoletja Nozadzejevo delo ostalo gruzijskim raziskovalcem neznano in nedostopno; preučiti razloge, zakaj se je pred začetkom »perestrojke« zdelo nesprejemljivo sklicevati nanj in določiti okoliščine, ki so omogočile rehabilitacijo Viktorja Nozadzeja kot državljana in raziskovalca. 
Maka Elbakidze

Ivane Javakhishvili Tbilisi State University

The Forbidden Homeland: Victor Nozadze's Scientific Activity from the Standpoint of Soviet Ideology

„Every Georgian abroad is a representative of his nation," - these words belong to the Georgian émigré writer and scholar Viktor Nozadze, who was doomed to live outside his homeland, endlessly wandering. The time of his creative maturity coincided with the period when the new Georgia, which started to be called Communist in 1921, blocked the way for all those who could not see the country's political future in red colors. The path of his dramatic life covers a fairly wide geographical area - France, Germany, Austria, Argentina, Chile, Brazil, Spain and finally France again ... During these thirty-year "wanderings" he created six monumental volumes which deal with the main problematics of Rustaveli“s „Vepkhistqaosani" ("The Knight in the Panther's Skin") - completely alone without any financial support, thanks to his enormous talent and will.

The research on „Vepkhistqaosani“, or, to use Niozadze's words, „the search“, was started by him in the Berlin period of his life at the end of World War II. As the scholar himself pointed out, his goal was to bring the investigated problematics of „Vepkhistqaosani“ into the system by studying Rustaveli's Weltanschauung and its connection to the world culture, making it easier for the next generation of researchers to place Georgian writing into the context of world civilization. The scholar rightly noted that the Georgian nation did not act as a supplier in the development of world culture, but was rather the recipient of this culture. The acceptance of culture and its processing in its own national consciousness, and its transfer to one's own national soil is not characteristic of all nations. And if the Georgian nation was the follower of the world culture and still is, this is, in Nozadze's opinion, the outcome of its national talent.

The aim of this paper is to show the ideological mechanism as a result of which Nozadze's work appeared to be unknown and inaccessible to Georgian researchers until the end of the fifties of the last century; to study the reasons for which it was unacceptable and inadmissible to refer to him as an author before the beginning of „perestroika“, and under what circumstances occurred the rehabilitation of Viktor Nozadze as a citizen and a scholar. 
Aleš Kozár

Univerza Pardubice

Iskanje podobe vasi v vrtincu ideoloških konfliktov 20. stoletja: Tematološka skica iz sodobne češke in slovenske literature

$\checkmark$ zadnjih petindvajsetih letih se $v$ slovenski književnosti motiv vasi pojavlja sorazmerno pogosto, bodisi kot prostor lirizacije in poetizacije eksotičnosti drugega (Lainšček, Tomšič) bodisi kot zapostavljen, temačen prostor brez prihodnosti (Ki jo je megla prinesla). $\checkmark$ češki literaturi je bila vas predvsem $v$ go. letih kot motiv skoraj nezanimiva, šele pozneje so jo avtorji začeli tematizirati kot prostor, ki je izrazito povezan z divjo, neukročeno naravo (Bajaja), kot prostor magičnih tradicij (Tučková) ali mesto skritih ideoloških konfliktov iz nedavne preteklosti (Hájíček). Vas je bila aktualizirana kot prostor ključnega ideološkega konflikta med absolutistično zlonamernostjo totalitarizma in vaško skupnostjo, ki so jo povezovali zemlja, vera in tradicija in ki naj bi jo bilo potrebno izruvati s temi koreninami vred. 
Aleš Kozár

University of Pardubice

Searching for an Image of a Village in the Vortex of the 2oth-century Ideological Conflicts:

A Thematological Sketch from Contemporary Czech and Slovenian Literatures

During the last twenty-five years, the motif of a village has appeared quite frequently in Slovenian literature, where it is present either as a space of lyricisation and poetisation of the exoticism of the Other (Lainšček, Tomšič), or as a neglected, dark space without future (Ki jo je megla prinesla). While Czech literature showed a lack of interest in the motif of a village in the 1990s, Czech writers have recently started to discover the village as a place distinctly connected with wild, untamed nature (Bajaja), magic traditions (Tučková), or a place of half-hidden ideological conflicts stemming from recent past (Hájičck). The village has gained considerable relevance as a place of the key ideological conflict between the absolutist bad-will of totalitarianism and the village community where the latter is one with the earth, faith, and tradition, and where the totalitarian regime tries to uproot the village community. 


\section{Gaga Lomidze}

Državna univerza Ivaneja Javakhishvilija v Tbilisiju

\section{Politika retorike in retorika politike}

Prispevek se ukvarja z razkrivanjem razmerij moči $v$ gruzijski posovjetski literaturi, in sicer $v$ leposlovnih in neleposlovnih besedilih devetdesetih let prejšnjega stoletja in z začetka tretjega tisočletja. Uporabili bomo diatetični pristop (aktivni, pasivni in srednji), hkrati pa posegli po metodah novega historizma, kulturnega materializma in kulturnih študij, ki nas bodo vodile po analizi gruzijskih literarnih besedil tranzicijskega obdobja (pesnikov, ki so ustvarjali v obdobju tik po državljanski vojni - Davida Chikhladzeja, Davida Barbakadzeja, Zuraba Rtveliashvilija in predstavnikov t.i. »Gagarinove generacije«) ter njihovi primerjavi s protisovjetskimi težnjami gruzijske literature sovjetskega obdobja. Takšen pristop nam bo omogočil $v$ diskurzivnih praksah prepoznati znake družbenih in političnih sistemov. Prav tako bomo razpravljali o funkciji, ki jo je imel smeh v bolečem procesu paradigmatskega premika v tranzicijski Gruziji ( $v$ zvezi s škandalozno in pogosto obravnavano pripovedjo Prvi Rus gruzijskega pisatelja Lashe Bugadzeja ter animirano politično in satirično serijo Kuga). 
Gaga Lomidze

Ivane Javakhishvili Tbilisi State University

\section{The Politics of Rhetoric and the Rhetoric of Politics}

The paper deals with the problem of how power relations reveal themselves in the post-Soviet Georgian literature, namely in the literary and non-literary texts of 1990 s and the beginning of 2000 s. We will use the diathetical (active, passive, medium) approach, as well as some methods introduced by New Historicism, Cultural Materialism and Cultural Studies, to analyze Georgian literary texts of the transitional period (post civil war poets - David Chikhladze, David Barbakadze, Zurab Rtveliashvili and representatives of the so called 'Gagarin generation') and compare them to the anti-Soviet tendencies present in the Georgian literature of the Soviet period. This approach will help us to identify signs of social and political systems in discursive practices. We will also discuss the function of laughter in the painful process of the paradigm shift during Georgia's transitional period (the scandalous and widely discussed story "The First Russian" by Lasha Bugadze and the animated political and satirical series "Pestilence"). 
Valter Milovan

Univerza Juraja Dobrile v Pulju

Pisanje Piera Paola Pasolinija med Komunistično partijo in Katoliško cerkvijo

Pier Paolo Pasolini (1922-1975) je v svojem pisanju razvil pogosto škandalozen način govorjenja o nosilcih oblasti $\vee$ Italiji, pa tudi njihovega neposrednega nagovarjanja, podajanja predlogov in kritiziranja. Pasolini v analiziranih besedilih (člankih iz časopisa Corriere della Sera, pesmih A un Papa in II PCl ai giovani!, esejih, prozi, filmih La ricotta in Uccellacci e uccellini) spregovori o ostankih fašizma $\vee$ italijanski družbi, inerciji Katoliške cerkve, nezmožnosti italijanske Komunistične partije, da bi prišla na oblast, ter o svetu drog in kriminala, ki nima obrazov.

Ker je o teh pojavih pisal na svojstven provokativen način, je bil Pasolini precej prisoten $v$ družbi svojega časa, prisoten pa je tudi še $v$ današnji. Pri tem je ustvaril celo nekaj metaforičnih izrazov, ki opisujejo razmere in razmerja $\vee$ Italiji druge polovice 20 . stoletja: il Palazzo (»Palača oblasti«), prima e dopo delle lucciole (delitev časa na obdobje »pred kresnicami in po njih«) itd. 
Valter Milovan

Juraj Dobrila University of Pula

\section{The Writing of Pier Paolo Pasolini between the Communist Party and the Catholic Church}

Pier Paolo Pasolini (1922-1975) developed in his writing an often scandalous way of talking about and with the holders of power in Italy, sometimes addressing them directly, making suggestions and criticizing them. In the analyzed texts (articles from the newspaper Corriere della Sera, poems A un Papa and II PCl ai giovani!, essays, prose, films La ricotta and Uccellacci e uccellini), Pasolini speaks about the remains of fascism in Italian society, the inertia of the Catholic Church, the inability of the Italian Communist Party to come to power in Italy, and drugs and criminality without a face.

Writing about these phenomena in a provocative way, Pasolini remained very present in the society of his time and is still present there today, having created even some metaphorical expressions that describe social relations in Italy in the second half of the 2oth century: il Palazzo (,the Palace of Power“), prima e dopo delle lucciole (,,before and after the disappearance of fireflies“) etc. 
Maja Murnik

Inštitut za nove medije in elektronsko literaturo, Ljubljana

Sodobne slovenske dramske pisave in družbenoangažirane uprizoritvene prakse

Prispevek izhaja iz zavedanja, da $\vee$ zadnjih desetletjih ni več smiselno strogo ločevati med dramatiko in gledališčem, kajti opraviti imamo $z$ »ne več dramo « (Poschmann) in $z$ ne več gledališčem oz. s postdramskim gledališčem (Lehmann). $\vee$ krizi reprezentacije in dramske forme $v$ ospredje stopajo performativne razsežnosti tekstov, ki postajajo barthesovski odprti teksti - heterogene, performativne in pomensko odprte strukture.

$\checkmark$ prispevku bomo $v$ luči njihove družbene angažiranosti in političnosti analizirali primere »ne več dram « Simone Semenič ter jih dopolnili z obravnavo primerov nedavnih družbenoangažiranih uprizoritev $v$ slovenskem gledališču, $v$ katerih je pomemben tekstovni del (npr. Metamorfoze 4: Črne luknje, Republika Slovenija, Odilo. Zatemnitev. Oratorij) in ki segajo od preprostih političnih agitk do kompleksnih obravnav družbenih tem. Koga nagovarjajo ti projekti in kaj želijo doseči?

Domet in moč njihove političnosti in družbene angažiranosti je treba razumeti $\vee$ kontekstu položaja umetnosti in gledališča $\vee$ sodobni družbi, pa tudi v kontekstu sodobne postpolitičnosti. Kje so danes mesta moči in kako jih nagovarjata ter se do njih opredeljujeta sodobna slovenska drama in gledališče? Kakšne strategije in taktike pri tem uporabljata ter kaj nam sporočata? 
Maja Murnik

Institute of New Media Art and Electronic Literature, Ljubljana

Contemporary Slovenian Dramatic Writing and Socially Engaged Staging Practices

The paper stems from the awareness that in the recent decades it has no longer made sense to distinguish strictly between dra$\mathrm{ma}$ and theatre as we are dealing with »no-longer-dramatic texts« (Poschmann) and the no-longer-theatre or the postdramatic theatre (Lehmann). In the crisis of representation and the dramatic form, performative dimensions of texts come to the foreground, as texts become Barthesian open texts - heterogeneous, performative structures which are open in terms of meaning.

In the paper, we will analyze examples of »no-longer-dramatic texts« by Simona Semenič in the light of their social engagement and politicality, and we will complement these by tackling their recent socially engaged stagings in Slovenian theatre, where the textual part plays a significant role (e.g. Metamorphoses 4: Black holes, Republic of Slovenia, Odilo. Obscuration. Oratorio) and which range from simple political agitation plays to complex treatments of social themes. Who do these projects address and what are they trying to achieve?

We need to understand the scope and power of their politics and their social commitment in the light of the position of art and theatre in contemporary society, including the context of contemporary postpoliticality. Where are the loci of power today and how are they addressed by contemporary Slovenian drama and theatre; what is their stand towards them? Which strategies and tactics do Slovenian drama and theatre use in the process and what is their message for us? 
Roland Orcsik

Univerza v Szegedu

Ekstaza in agonija

Prispevek bo predstavil madžarsko literarno, umetniško in politično revijo Új Symposion (1965-1992) iz Novega Sada (Vojvodina, Srbija) - najbolj progresivno madžarsko (neo)avantgardistično glasilo. Njegove subverzivne literarne in vizualne eksperimente so navdihovali umetniki in filozofi z območja bivše Jugoslavije (Bosanci, Hrvati, Slovenci, Srbi itd.). Prispevek bo obravnaval težave, s katerimi se sooča manjšinska književnost (Deleuze-Guattari), možnosti in oblike umetniške avtonomije $v$ ambivalentnem jugoslovanskem sistemu, problem »od zgoraj upravljane večkulturnosti« (Alpár Losoncz) ter problem kulturne in politične provincialnosti (Radomir Konstantinović). Hipoteza prispevka je, da je ambivalentni politični sistem ustvaril prav tako ambivalentne umetniške strategije. 
Roland Orcsik

University of Szeged

\section{Ecstasy and agony}

The paper will present the Hungarian literary, political and art magazine „Új Symposion” (1965 - 1992) from Novi Sad (Voivodina, Serbia). This was the most progressive Hungarian (neo)avantgarde periodical. Its subversive literary and visual experiments were inspired by Yugoslavian (Bosnian, Croatian, Serbian, Slovenian etc.) artists and philosophers. The contribution will discuss the problems of minority literature (Deleuze-Guattari), the possibilities and forms of artistic autonomy in the ambivalent Yugoslavian system, the problem of »multiculturalism controlled from above« (Al, pár Losoncz) and the problem of cultural and political provincialism (Radomir Konstantinović). The paper's hypothesis is that the ambivalent political system led to the creation of equally ambivalent artistic strategies. 
Marcello Potocco

Univerza na Primorskem

\section{ZDA kot 'drugi’ v kanadskem nacionalizmu}

$\checkmark$ prispevku bom predstavil dva primera nacionalne ideologije $v$ kanadskem literarnem sistemu. Skupna jima je napetost, ki je bila do nedavnega še prisotna $v$ odnosu, ki ga kanadska literatura zavzema do Združenih držav Amerike. Napetost v odnosu do Združenih držav, ki je bila običajno preučevana znotraj trikotnika Velika Britanija - Kanada - Združene države Amerike, je bila v kanadski literarni vedi zaznana razmeroma zgodaj. Sam se bom osredotočil na mehanizme sprejemanja in zavračanja vplivov dominantnejše književnosti in kulture nasproti manj dominantni kanadski književnosti. Prvi primer bo poezija Archibalda Lampmana. Njegova poezija izkazuje tako vpliv ameriške transcendentalistične filozofije kot tudi strah $v$ odnosu lirskega subjekta do narave, ki ni tipična značilnost transcendentalističnih avtorjev. Lampmanova poezija je tako tipični primer dvojnosti, ki se kaže $v$ odnosu do drugega, v kanadski samoidentifikaciji. Najbrž pa se je prav zaradi očitnosti ameriško-kanadskega binoma zgodilo, da na vrhuncu kanadskega nacionalizma, $v$ šestdesetih letih, Lampmanova poezija ni doživela tolikšne pozornosti, kot so jo zagovorniki kanadskega literarnega nacionalizma (zlasti M. Atwood) posvečali drugim avtorjem. Drugi v prispevku obravnavani primer prav tako kaže na ameriško-kanadsko napetost, a ne le na ravni literarne oblike; napetost se je namreč jasno izkazala $v$ obliterarnih bojih med zagovorniki ameriške t.i. postmoderne estetike in varuhi kanadske nacionalistične mitopoetske šole. Milton Acorn je bil ena centralnih osebnosti v nacionalističnih krogih, pretežno zbranih $\vee$ Torontu. $\vee$ prispevku prikažem njegov status v zgoraj omenjenem boju, a pokažem tudi, da njegova poezija še zdaleč ni imuna na značilnosti t.i. ameriške postmodernistične poezije. Oba obravnavana primera pa nam pokažeta, da je napetost $v$ odnosih med obema državama in literaturama obstajala, a tudi to, da se je $v$ času nacionalizma skušalo zakriti prisotnost binoma $v$ kanadskih literarnih delih. 
Marcello Potocco

University of Primorska

\section{The USA as 'the Other' in Canadian Nationalism}

In my paper, I will present two examples of national ideology at work in the Canadian literary system. They both exhibit the tension present in Canadian literature in relation to the literature and culture of the United States. Canadian literary criticism detected this problematic relationship quite early on, when what was usually analyzed was the triangle of the relations between the United Kingdom, Canada and the USA. I will focus on mechanisms of accepting and rejecting the influences of the dominant US literature in relation to Canadian poetry. My first example is the poetry of Archibald Lampman. Lampman's poetry shows some influences of American transcendentalism, but what is unique is the speaker's distance towards and fear of nature, which is not common for original transcendentalism. Lampman's poetry is thus a typical example of the American-Canadian binome present in Canadian national identification. Possibly it was due to the evidentness of this binarism that the proponents of Canadian literary nationalism in the 1960 s (Frye, Atwood) considerably neglected Lampman's poetry. The second example presented in the paper epitomizes the American-Canadian binome not merely at the level of the literary form, but also in the meta-literary sphere, in the struggle between the advocates of the so called American postmodern poetics and the defenders of the Canadian nationalist mythopoetic school. Milton Acorn was one of the central figures of the Ontario-based nationalist circle. In my contribution I argue that the famous »People's Poet Award « conflict between Acorn and George Bowering was only an external display of the American-Canadian tension which was also internal, since Acorn's poetry incorporated some postmodern features under the influence from the US. Both examples reveal the strong presence of the American-Canadian tension, but the latter also shows that at the peak of Canadian literary nationalism there existed a clear tendency to conceal any possible elements of »Americanism《. 
Irma Ratiani

Državna univerza Ivaneja Javakhishvilija v Tbilisiju

\section{Od vojne do miru: Literarno življenje Gruzije po drugi svetovni vojni}

Po drugi svetovni vojni je $v$ Sovjetski zvezi prišlo do pomembnih političnih sprememb. Možnarji so utihnili; leta 1953 je preminil Josip Stalin, Gruzijec in zato utelešeni simbol države; kmalu je sledil razvpiti Dvajseti kongres Komunistične partije Sovjetske zveze, ki mu je načeloval Nikita Hruščov (1956). Hruščovov govor, naperjen proti Stalinu, je v Gruziji zanetil resne politične nemire s človeškimi žrtvami, kar se je končalo s tragičnimi dogodki 9. marca 1956. Še vedno ni jasno, ali je šlo za politično stališče ali izraz ranjenega nacionalnega ponosa.

Toda kmalu po tem je na celotnem območju Sovjetske zveze nastopila t.i. »odjuga« (Otteppel); bobnenje možnarjev je zamenjal ritmični tvist, ki ga je vrtinčilo z zahoda. Literarni proces obdobja »odjuge« (termin Ilje Erenburga) je porodil precej drugačno sliko od tiste, ki je opisovala predhodna desetletja sovjetskega življenja; v razmerah politične liberalizacije so postale $v$ gruzijskem literarnem prostoru opazne drugačne težnje: po eni strani očitna nostalgija po Stalinu, po drugi krepitev specifičnega modela neorealizma in - kar ni nič manj pomembno - vzpon pisanja žensk.

Pričujoči prispevek se posveča opisovanju in analizi vseh omenjenih tendenc. 
Irma Ratiani

Ivane Javakhishvili Tbilisi State University

\section{From War to Peace: The Literary Life of Georgia after World War II}

After World War II, significant political changes occurred in the Soviet Union. Trench mortars were silenced; in 1953 Joseph Stalin, originally a Georgian and thus the embodied symbol of the country, died; soon followed the much talked about XX Assembly of the Communist Party of the Soviet Union headed by Nikita Khrushchev (1956). Khrushchev's speech against Stalin sparked in Georgia a serious political unrest with casualties which ended with the tragic events of March 9, 1956. It is still unclear whether the events were the result of a political position or the demonstration of insulted national pride.

However, soon afterwards the so called Otteppel ("the Thaw") was established in the entire territory of the Soviet Union; the thundering of trench mortars was substituted by the rhythmic twist whirling from the West. The literary process of the "thaw" period (Ilia Erenburg's term) yielded quite a different picture from the one that described the previous decades of Soviet life; in conditions of political liberalization, new tendencies were noticed in Georgian literary space: on the one hand - the obvious nostalgia for Stalin, on the other - the onset of a specific model of neo-realism and, what is of no less importance, the rise of women's writing.

The paper deals with describing and analyzing all of these tendencies. 
Janez Strehovec

Inštitut za nove medije in elektronsko literaturo, Ljubljana

\section{Slovenski literarni nacionalizem kot ideološki aparat države}

Za razumevanja političnega $\vee$ postsocialističnih evropskih državah je bistveno upoštevanje družbenega mesta kulture, ki v teh državah nastopa $v$ številnih pomembnih vlogah. S kulturo tukaj mislimo predvsem na literaturo in druge umetnosti, za katere je $v$ sedanjosti bistveno, da opravljajo vrsto družbenih funkcij, ki niso vezane ne na literarnost in ne na estetiko (srečujemo se $z$ deli, ki niso nobena dela več in s konceptom ne-samo-umetnosti). $\vee$ tem referatu opozarjamo na primer Slovenije, v kateri ima literarna kultura (kot kultura avtorjev in literarnih intelektualcev) izjemen družbeni položaj (vrsta inštitucij poudarja ključni položaj literature za narodovo identiteto), hkrati pa je literatura generator ideologije in ritualov, ki so skrajno regresivni in iracionalni. $\vee$ tem pogledu namenjamo kritično pozornost t.i. literanemu nacionalizmu, ki ga interpretiramo kot enega ključnih ideoloških aparatov slovenske države.

Literarni nacionalizem izrablja številne mehanizme moči za vsiljevanje literarne kulture, še posebno izobraževalni aparat, inštitucijo literarne pismenosti, kritiko, medije, mednarodne prireditve (festivale), nacionalne svečanosti, podelitve nagrad, praznike. Pri tem se poveličuje in predstavlja narod, kajti zgodba literarnega nacionalizma se začenja s silogizmom:

Literati konstituirajo slovenski narod.

Jaz sem literat.

Jaz konstituiram slovenski narod.

Literarni nacionalizem kot ideološki aparat (Althusserjev koncept) slovenske države nima nič opraviti z literarnostjo, poetiko, estetiko, ustvarjalnostjo, zanima ga predvsem ideologija, ki jo konstruira iz literature za politično-propagandne namene. Kritika literarnega nacionalizma se zato ne usmerja na literarna dela in na dejavnost pisanja, nič skupnega nima ne z ljubeznijo ne s sovraštvom do literature, ampak se nanaša na inštitucije, ki tvorijo literarno-ideološki, interpretativni in propagandni kontekst, $v$ katerega se umešča nacionalna literarna produkcija, ki jo ta nacionalizem izrablja za svoje neliterarne cilje. Pri tem gre za strategijo nacionalne politike, ki si prizadeva za oblikovanje kar se da stabilnega nacionalnega konsenza tako, da vrsto svojih neoliberalističnih in globalizacijskih projektov in praks nevtralizira s tem, da dopusti arhaično nacionalliteratsko ideologijo in njene inštitucije. 
Janez Strehovec

Institute of New Media Art and Electronic Literature, Ljubljana

Slovenian Literary Nationalism as an Ideological State Apparatus

To understand the political in postsocialist European countries it is essential to consider the social position of culture which plays numerous important parts in these countries. What we refer to by the term culture is primarily literature and other arts for which it is currently essential that they perform a series of social functions not related to either literariness or aesthetics (we are encountering works which are no-longer-works and the concept of not-only-art). In the paper we focus on the example of Slovenia where literary culture (defined as the culture of authors and literary intellectuals) enjoys a special social position (a number of institutions emphasize the indispensable role of literature for nation's identity) and where literature at the same time generates extremely regressive and irrational rituals and ideology. In this regard, we will pay critical attention to the so called literary nationalism, which is interpreted as one of the key ideological apparatuses of the Slovenian state.

Literary nationalism exploits numerous mechanisms of power for imposing literary culture on people, especially the educational apparatus and institutions of literary literacy, criticism, media, international events (festivals), national ceremonies, award ceremonies, holidays. In all of these instances it is the nation that is glorified and highlighted, since the story of literary nationalism starts with the syllogism:

Writers constitute the Slovenian nation.

I am a writer.

I constitute the Slovenian nation.

Literary nationalism as an ideological apparatus (an Althusserian concept) of the Slovenian state has of course nothing to do with literariness, poetics, aesthetics, or creativity, since it is interested in ideology which it constructs from literature for the purposes of political propaganda. The critique of literary nationalism is thus not directed at literary texts and the activity of writing; it has nothing to do with either love or hate towards literature; it refers to institutions that make up the literary-ideological, interpretative and propaganda context into which the national literary production is placed, (mis)used by this nationalism for non-literary ends. This is a strategy of national politics which works to form a stable national consensus and tries to neutralize a number of its neoliberal and globalization projects and practices by supporting the archaic national-authorship ideology and its institutions. 
Andrei Terian

Univerza Luciana Blage v Sibiuju

\section{Rekodiranje modernizma $v$ romunski literarni kulturi v obdobju 'liberalnega' komunizma}

Prispevek raziskuje, kako sta romunska književnost in literarna veda v obdobju »liberalnega« komunizma (1964-1971) odkrili, obnovili in predvsem rekodirali modernizem. Prispevek uporabi $v$ ta namen kot izhodišče za primerjavo razvoj poznega modernizma $v$ zahodnih književnostih (prb. 1945-1965) kot radikalne, eksperimentalne, pogosto konceptualne in »angažirane« umetnostne smeri. V obratni smeri pa je vzpon socialističnega realizma prekinil evolucijo modernizma $\vee$ vseh vzhodnoevropskih književnostih; v romunski književnosti je zavračanje modernizma, denimo, med letoma 1956 in $195^{8}$ spodbudilo več intenzivnih medijskih kampanj. Vendar pa je bil modernizem $\vee$ Romuniji, kljub tovrstnim poskusom zatrtja, $v$ šestdesetih letih prejšnjega stoletja rehabilitiran, in sicer na dva načina: najprej preko ponovnega odkrivanja modernistične tradicije romunske medvojne literature in, drugič, preko prakticiranja in podpiranja »neomodernistične« literature, ki se je poskušala (re)sinhronizirati z zahodnimi kulturami. Glavna teza pričujočega prispevka je naslednja: če je $v$ zahodnih književnostih pozni modernizem deloval kot taktika oporekanja oblastem in izzivanja politične disrupcije, pa je romunski neomodernizem deloval prej kot način legitimiziranja družbene kohezije in, natančneje, poststalinističnega ideološkega sistema; kljub temu, da je bil neomodernizem sprva sprejet kot subverzivno orodje (t.j. kot orožje proti socialističnemu realizmu), je njegovo rekodiranje $v$ »humanističnih« in povsem »estetskih« tonih kmalu zadušilo njegov politični in ideološki potencial. 
Andrei Terian

Lucian Blaga University of Sibiu

\section{Recoding Modernism in Romanian Literary Culture during 'Liberal' Communism}

This paper explores how the Romanian literature and criticism of the 'liberal'-communist era (1964-1971) recovered and, more importantly, recoded modernism. To this end, my study uses as a benchmark the development of late modernism in Western literatures (c. 1945-1965), as a radical, experimental, often conceptual and 'committed' form of art. Conversely, the emergence of socialist realism interrupted the evolution of modernism across East European literatures; for example, in Romanian literature, the rejection of modernism sparked several harsh press campaigns between 1956-1958. Yet, despite these attempts, modernism was recovered in Romania over the 1960s, in two ways: first, by rediscovering the modernist tradition of interwar Romanian literature, and second, by practicing and supporting 'neo-modernist' literature that sought to (re)synchronize itself with Western cultures. However, the main thesis of my paper is that, if in Western literatures late modernism served as a tactic of challenging the establishment and causing political disruption, Romanian neomodernism functioned rather as a way of legitimizing social cohesion and, in particular, the post-Stalinist ideological system; although neomodernism was launched as a subversive tool (i.e. as a weapon against socialist realism), its recoding in a 'humanist' and purely 'aesthetic' key soon suppressed its political and ideological potential. 
Tomaž Toporišič

Univerza $\vee$ Ljubljani

\section{Ali lahko umetnost posega $v$ diskurzivni pretok (dez)informacij $v$ času globalnih negotovosti?}

Živimo v desetletju silne negotovosti, kar se tiče sredstev, ciljev in meja »glokalnih« družb, ki se spopadajo s humanitarnimi katastrofami, terorizmom in postkolonializmom. Da bi preučili, kako se književnost in umetnost vključujeta $v$ pretok signifikacij in reprezentacij, ki gradijo družbeno resničnost, se bomo poslužili dveh primerov. Prvega predstavljajo romani Winfreda Georga Sebalda, z beganjem med »znaki«, ki ga prekinjajo črno-bele fotografije - Nicholas Bourriaud jih pojmuje kot simbol mutacije $v$ našem zaznavanju prosto$r a$ in časa, $v$ katerem se zgodovina in geografija medsebojno oplajata, izrisujeta poti in pleteta mreže. Drugi primer je delo Oliverja Frljića, bosansko-hrvaškega gledališkega režiserja, ki posega v svojih šokantnih predstavah po lastnih osebnih, vojnih ter političnih travmah, da bi lahko zastavljal univerzalna vprašanja o mejah umetniške in družbene svobode, odgovornosti posameznika in skupnosti, strpnosti in stereotipih. Poskušali bomo izrisati teren sodobnih subjektivnosti tako »doma« kot »na frontni črti«. Onkraj preučitve izpodbijanja subjektnih pozicij $\vee$ domačih in (pred)mestnih okoljih bomo zasledovali figure, ki prestopajo meje in naseljujejo premična bojišča današnje Evrope ali širše. Poskušali bomo razumeti ne dihotomijo, ampak dialektiko »umetnosti« in »družbe«, znotraj katere fluidni, neobvladljivi subjekti nenehno spreminjajo obrise. Kritiški konsenz o tem, da se sodobna umetnost prvenstveno ukvarja z realnim, bomo postavili pod vprašaj ter poskušali opisati, kako sodobno gledališče in književnost krmarita po kompleksnosti diskurza in družbene resničnosti neoliberalizma v dobi terorizma. Kako se umetnost pogaja, kako modulira in sodeluje $v$ diskurzivnem pretoku zgodb, idiomov, polemik, pričevanj in delčkov (dez)informacij pri soočanju z globalnimi negotovostmi. 
Tomaž Toporišič

University of Ljubljana

Can Art Negotiate the Discursive Circulation
of (Mis)information in the Face of Global Insecurities?

We are living in the decade of intense uncertainty surrounding the means, ends and limits of the "glocal" societies dealing with issues of humanitarian catastrophes, terrorism and post-colonialism. For purposes of our examination of how literature and art take part in the circulation of significations and representations in the construction of social reality we will use two examples. The first one are the novels by Winfred Georg Sebald, his wanderings between 'signs', punctuated by black and white photographs, which Nicholas Bourriaud defines as emblematic of a mutation in our perception of space and time, in which history and geography operate a cross-fertilization, tracing out paths and weaving networks. Our second example is Oliver Frljić, Bosnian-Croatian theatre director, with his disturbing, shocking performances in which he uses his own personal, wartime and political traumas to ask universal questions about the boundaries of artistic and social freedom, individual and collective responsibility, tolerance and stereotypes. We will try to chart the terrain of contemporary subjectivities both 'at home' and 'on the front line'. Beyond examining the contestation of subject positions in domestic and (sub)urban settings we will follow border-crossing figures to the shifting battlefields of today's Europe and beyond. We will try to grasp not a dichotomy but a dialectics of 'art' and 'society', where fluid, uncontainable subjects are constantly pushing the contours. Revising the critical consensus that contemporary art primarily engages with the real, we will try to describe how today's theatre and fiction navigate the complexities of the discourse as well as social realities of neo-liberalism in the age of terrorism. In what way does art negotiate, inflect, and participate in the discursive circulation of stories, idioms, controversies, testimonies, and pieces of (mis)information in the face of global insecurities. 


\section{Gašper Troha}

Univerza v Ljubljani

\section{Družba v slovenski dramatiki pod socializmom in danes}

Slovenska dramatika se je $v$ svoji zgodovini nenehno odzivala na družbeno dogajanje. $\vee$ obdobju med letoma 1945 in 1990, ki ga je zaznamovala socialistična družbena ureditev, je dobila še posebno funkcijo družbenega foruma, saj so intelektualci prav $v$ dramatiki in gledališču lahko izrazili kritiko sistema ter preskušali njegove alternative. Nič čudnega torej, da je bilo politično gledališče po mnenju Dušana Jovanovića, enega osrednjih dramatikov tega časa, najbolj popularen teater tega obdobja.

Po I. 1990 je potreba po alternativnem prostoru svobodnega izražanja s spremembo sistema $\vee$ parlamentarno demokracijo izginila, kljub temu pa slovenska dramatika še vedno tematizira tudi polpreteklo zgodovino. Seveda jo sedaj kontrastira s sodobnostjo in v njej odkriva drugačno vsebino. Prav razlike med dojemanjem in predstavljanjem socializma nekoč in danes pa nam bržkone lahko služijo kot sredstvo za razmislek o položaju dramatike in gledališča $v$ družbi.

Ta vloga namreč bistveno določa podobo slovenske dramatike $v$ obdobju nekdanje Jugoslavije, najverjetneje pa je od nje odvisna tudi dandanes.

Prispevek se bo lotil primerjave dveh dramskih tekstov: Vojaške skrivnosti Dušana Jovanovića (krstno uprizorjena 14. 10. 1983 v SSG Trst, režiser Slobodan Unkovski) in tisočdevetstoenainosemdeset Simone Semenič (krstno uprizorjena 11. 5. 2016 v SNG Maribor, režiserka Selma Spahić). 
Gašper Troha

University of Ljubljana

\section{Society in Slovenian Drama under Socialism and Today}

Slovenian dramatic literature has constantly reacted to social developments throughout its history. In the period between 1945 and 1990 , which was marked by the socialist political regime, drama gained a special function by acting as a social forum, since it was in drama and theatre that intellectuals could articulate their critique of the political system as well as test out its alternatives. It thus comes as no surprise that political plays were the most popular form of theatre of this period, according to Dušan Jovanović, one of the seminal playwrights of this time.

Since 1990 there has been no need for an alternative space of free expression, as the political system changed to parliamentary democracy, but Slovenian drama still thematizes recent history. It now contrasts the country's socialist history with contemporary time, revealing the past's content in a different light. The differences between perceiving and presenting socialism in the past and today can serve as a means for thinking about the role and position of drama and theatre in society.

It is this very role that essentially determined the image of Slovenian drama in the period of former Yugoslavia, while most probably still characterizing it today.

The paper will attempt a comparison between two dramatic texts: Military Secrets (Vojaške skrivnosti) by Dušan Jovanović (with the first night on 14. 10. 1983 at Slovensko stalno gledališče Trst, directed by Slobodan Unkovski) and tisočdevetstoenainosemdeset by Simona Semenič (with the first night on 11. 5. 2016 at Slovensko narodno gledališče Maribor, directed by Selma Spahić). 
Jonatan Vinkler

Univerza na Primorskem

"Svoji k svojim《 ali „V štacuno nemškutarjevo ne hodi!»

Prispevek se osredotoča na mednacionalni boj med Slovenci in Nemci, ki je bil posledica vse bolj določno izoblikovane slovenske in nemške nacionalne identitete ter identifikacije na Kranjskem in se je od druge polovice šestdesetih let 19. stoletja s političnega vse bolj prenašal tudi na gospodarsko področje. $V$ središču razprave so diskurzivne prakse in narativi nacionalizma $\vee$ dotlej »nezaznamovanem « družbenem podsistemu, ekonomiji. V razvid prihajajo besedila in drugi znaki (karikature) $\vee$ Novicah, Slovencu in Laibacher Tagblatt/Zeitung, in sicer ob slovenskem bojkotu nemško govorečih (nemških in nenemških) podjetij in obrtnikov, ki doseže enega vrhov z množično slovensko »zaporo« za zvonove znamenite livarne Alberta Samasse (1875). Ugotoviti je, da je tretja faza oblikovanja slovenske narodne identitete (ob kulturni in politični identiteti se razvije tudi ekonomska) hkrati faza, ko se zdi, da identitetno vprašanje slovenskega jezika preči in osmišlja vse družbene podsisteme in transcendira vsako družbeno delovanje, hkrati pa ves diskurz zvaja na eksplicitno izrekanje identitetnih znakov (govorjenje slovenskega ali nemškega jezika kot pogoj za delovanje družbenih sistemov). 
Jonatan Vinkler

University of Primorska

\section{"stick to Your Own Kind" or "Don't Set Foot in Krauts' Shops!«}

The paper focuses on the inter-national struggle between Slovenians and Germans, which resulted from the increasingly distinctly developed Slovenian and German national identities and identification in Carniola. From the second half of 1860 s onwards, this struggle was moving from the field of the political into that of business and enterprise, too. At the centre of our attention are the discursive practices and narratives of nationalism present in the previously »unmarked《 social subsystem, economy. What comes to light are texts and other signs (caricatures) from the newspapers Novice, Slovenec and Laibacher Tagblatt/Zeitung; to be more specific, the Slovenian boycott of German-speaking (both German and non-German) companies and craftsmen, which reached one of its highlights with a Slovenian mass »blockade« of bells produced in the famous Albert Samassa's foundry (1875). The third stage of the establishment of Slovenian national identity (in addition to cultural and political identity, we witness the development of the economic one) is at the same time the phase during which it seems that the identity question of the Slovenian language traverses - and gives sense to - all social subsystems and transcends all social action, while simultaneouly reducing all discourse to the explicit expression of identity signs (speaking the Slovenian or German language as a condition for the operation of social systems). 
Špela Virant

Univerza $\vee$ Ljubljani

Koncepcije družbenih funkcij literature v sodobnih besedilih severnoameriških staroselcev

»Marx se je navdihoval ob branju o določenih skupnostih ameriških staroselcev, ampak kot Evropejec seveda marsičesa ni dobro razumel« (Silko 1992, 519), je zapisala Leslie Marmon Silko (Laguna Pueblo) v romanu Almanac of the Dead. Marx in Engels sta brala predvsem dela ameriškega antropologa Lewisa $\mathrm{H}$. Morgana, ki je s svojo študijo o organizaciji irokeških skupnosti neposredno vplival na Engelsovo študijo Izvor družine, privatne lastnine in države. Sodobna literatura in literarna veda severnoameriških staroselcev danes, razpeta $\vee$ anahronizmu med globalizirano družbo in podrejenim položajem $\vee$ državah nekdanjih kolonizatorjev, zelo burno in kritično obravnavata osrednja družbeno-politična vprašanja: kritično do kapitalizma, ki je botroval verjetno največjemu genocidu $v$ zgodovini človeštva, kritično do komunističnih diktatur, do nacionalizmov, pa tudi do postkolonialnih teorij (zlasti koncepta hibridnosti). $\checkmark$ iskanju lastne poti, »intelektualne suverenosti«, ki bi se izognila pastem omenjenih ideologij, se avtorji pogosto sklicujejo na specifično epistemologijo in nujnost njene emancipacije. Pejorativne in romantizirane predstave, da imajo »ameriški staroselci modrost, Anglo-Američani pa znanost« opozarjajo na nujnost »dekolonializacije znanja« (Mignolo). Kakšna je ta epistemologija? In kakšna je v njej vloga jezika in pripovedništva? Prispevek bo odgovore na zastavljena vprašanja iskal v izbranih delih avtorjev kot so N. Scott Momaday, Leslie Marmon Silko ter Sherman Alexie. 
Špela Virant

University of Ljubljana

\section{Social Functions of Storytelling in Contemporary Native American Literature}

"Marx had been inspired by reading about certain Native American communal societies, though naturally as a European he had misunderstood a great deal”, wrote Leslie Marmon Silko (Laguna Pueblo) in her novel Almanac of the Dead. Marx and Engels read the work of the American anthropologist Lewis H. Morgan. Especially Engels in his The Origin of the Family, Private Property and the State referred to Morgan's writings about the ethnography of the Iroquois. Contemporary Native American writers and scholars discuss central social and political questions from a somehow anachronistic position between a globalized society and their status as "domestic dependent nations". They formulate a critique against capitalism that caused the genocide and against communist dictatorship, nationalism and postcolonial theories (especially the concept of hybridity). In the struggle for "intellectual sovereignty" that would avoid the pitfalls of these ideologies, they stress their specific epistemology and the need for its emancipation. Derogative and romantic notions - e.g. "Native Americans have wisdom, Anglo Americans have science" - call for "decolonializing and decolonial knowledges" (Mignolo). How can this epistemology be described? What is the role of language and storytelling in it? The paper will try to find answers in selected works by Native American authors N. Scott Momaday, Leslie Marmon Silko, and Sherman Alexie. 



\section{udeleženci participants}


Ştefan Baghiu is a teaching assistant of Romanian literature and literary theory at the Lucian Blaga University of Sibiu, Romania. His main fields of research include literary translation as a cultural phenomenon, quantitative literary research, cultural studies and Romanian postwar literature. He has published studies in Studia Philologia and Transilvania Review and has carried out a research project in Greensboro, NC, USA. He also writes essays, mainly for the Cultura review in Bucharest.

Ştefan Baghiu je asisten za romunsko literaturo in literarno teorijo na Univerzi Lucijana Blaga v Sibiu. Njegova raziskovalna področja vključujejo literarni prevod kot kulturni fenomen, kvantitativne literarne raziskave, kulturne študije in romunsko povojno literaturo. Objavljal je v revijah Studia Philologia in Transilvania ter raziskoval v raziskovalnem projektu v Greensboru (ZDA). Prav tako piše eseje, večina za revijo Cultura iz Bukarešte.

Varja Balžalorsky Antić is literary theorist, poet and translator. She works as Assistant Professor at the Faculty of Arts in Ljubljana. Her main research fields include theory of poetic discourse, subjectivity in literary discourse, rhythm analysis, contemporary poetry and Medieval French literature. She has translated from French and Serbian. She is the author of a collection of poems Vera Revjakina's B. Hat. Her monograph Lyrical subject. A Reconceptualisation will appear this year.

Varja Balžalorsky Antić je literarna teoretičarka, pesnica in prevajalka. Poučuje na Oddelku za primerjalno književnost in literarno teorijo Filozofske fakultete $v$ Ljubljani. Ukvarja se zlasti s teorijo pesemskega diskurza, subjektiviteto $v$ literarnem diskurzu, ritemanalizo, sodobno poezijo in srednjeveško francosko literaturo. Prevaja iz francoščine in srbščine. Je avtorica pesniške zbirke Klobuk Vere Revjakine B. Letos bo izšla njena monografija Lirski subjekt. Rekonceptualizacija.

Ana Beguš graduated in Translation Studies at the Faculty of Arts, University of Ljubljana, and received her doctoral degree in Philosophy and Theory of Visual Culture at the Faculty of Humanities Koper, University of Primorska. She lectures and does research in the fields of Lingustics, Translation Studies and Semiotics, with special emphasis on the analysis of the relation between text, discourse and technology. She is also an active translator from English and Italian.

Ana Beguš je diplomirala iz prevajalstva na Filozofski fakulteti Univerze $v$ Ljubljani, doktorirala pa iz Filozofije in teorije vizualne kul- 
ture na Fakulteti za humanistične študije Univerze na Primorskem. Predavateljsko in raziskovalno deluje na področju jezikoslovja, prevodoslovja in semiotike, s posebnim poudarkom na analizi razmerja med besedilom, diskurzom in tehnologijo. Dejavna je tudi kot prevajalka iz angleškega in italijanskega jezika.

Maka Elbakidze, Ivane Javakhishvili Tbilisi State University, Deputy Director of Shota Rustaveli Institute of Georgian Literature. Her interest includes: Rustaveli studies, Old Georgian Literature, Comparative literary studies, Émigré literature. Author of more than 70 published scholarly articles; this year her second monograph was published: The Man in the Panther's Skin in the Context of Medieval Literature (Lambert Academic Publishing). She is editor in chief of a review Literary Researches.

Maka Elbakidze, Državna univerza Ivane Javakhishvili Tbilisi, namestnica vodje inštituta Shota Rustaveli. Njene raziskave vključujejo študije Rustavelija, starejšo gruzijsko književnost, primerjalno književnost ter študije izseljenstva. Je avtorica več kot 70 znanstvenih člankov, letos je izdala svojo drugo monografijo. V panterja oblečeni človek $v$ kontekstu srednjeveške literature (Lambert Academic Publ.). Je glavna urednica revije Literarne raziskave.

Aleš Kozár works as a lecturer on Slovenian literature and culture at the University of Pardubice, Czech Republic. In addition to scientific papers he also concentrates at translating of Slovenian literature into Czech language. He translated works of Vladimir Bartol, Polona Glavan, Lojze Kovačič, Feri Lainšček, Primož Repar, and Goran Vojnović. In Czech (Souvislosti, Host) and Slovenian (Apokalipsa, Locutio) magazines he also published some of his poetry works.

Aleš Kozár predava o slovenski literaturi in kulturi na Univerzi Pardubice na Češkem. Poleg pisanja strokovnih člankov o slovenski literaturi 19. In 20. stoletja se posveča tudi prevajanju slovenske književnosti, objavil je npr. knjižna dela Vladimirja Bartola, Polone Glavan, Lojzeta Kovačiča, Ferija Lainščka, Primoža Reparja in Gorana Vojnovića. $\vee$ čeških in slovenskih revijah je objavil tudi nekaj odlomkov iz svoje pesniške dejavnosti.

Gaga Lomidze completed his $\mathrm{PhD}$ and is now the head of the Department of Literary Studies and Comparative Literature at the Shota Rustaveli Institute of Georgian Literature, he also teaches Theory of Literature at the Tbilisi State University. He is president of Georgian Comparative Literature Association (GCLA) and a member of the ICLA. He is one of the founders of Internation- 
al Summer School of Translation. Author of numerous articles and papers, he is the translator of nine books.

Gaga Lomidze je doktoriral na Inštitutu Shota Rustaveli za gruzijsko književnost, kjer je zdaj predstojnik Oddelka za literaturo in primerjalno književnost; poučuje na Državni univerzi v Tbilisiju. Je predsednik gruzijske in član mednarodne zveze za primerjalno književnost. Je eden od ustanoviteljev Mednarodne šole prevajalstva. Je avtor številnih člankov in prevajalec devetih knjig.

Valter Milovan, assistant professor at the High school Juraj Dobrila in Pula, Croatia, has published thre monographs Bilješke o Pasoliniju (Meandar 2011.) and Hrvatsko-talijanski razgovorni priručnik (Dominović 2011). In 2018 a book with his translations of Pier Paolo Pasolini will be published. He is holding the position of the secretary of the scientific association Mediteran.

Valter Milovan je docent na Vseučilišču Juraja Dobrile v Puli, Hrvaška. Je tajnik znanstvenega združenja Mediteran; objavil je tri knjige: Bilješke o Pasoliniju (Meandar 2011.), Hrvatsko-talijanski razgovorni priručnik (Dominović 2011) ter v soavtorstvu z Goranom Filipijem in Slavkom Kalčićem Rječnik roverskih i lokolnih govora (Dominović, Matica hrvatska, Mediteran, 2014). V letošnjem letu bo izšla knjiga s prevodi pesmi Pier Paola Pasolinija.

Maja Murnik graduated in theatre studies and in comparative literature in Ljubljana. She holds PhD in philosophy and theory of visual culture (at Faculty of Humanities, University of Primorska). She worked as Assistant at Faculty of Humanities and as editor-in-chief of the journal of performing arts Maska and its book editions. Currently she is freelance art critic. She is also a co-founder of the Institute of New Media Art and Electronic Literature (www.inm.si).

Maja Murnik je diplomirala iz primerjalne književnosti in iz dramaturgije (oboje $v$ Ljubljani) ter doktorirala iz filozofije in teorije vizualne kulture na Fakulteti za humanistične študije Univerze na Primorskem. Zaposlena je bila kot asistentka na Fakulteti za humanistične študije in kot urednica revije Maska ter njenega knjižnega programa, zdaj pa je samozaposlena $\vee$ kulturi (kot kritičarka/ recenzentka). Je tudi soustanoviteljica Inštituta za nove medije in elektronsko literaturo (www.inm.si).

Roland Orcsilk was born in Becse (Serbia). Since 1992 he lives in Szeged, Hungary, there he works at the University of Szeged. Orcsik is one of the editors of literary monthly "Tiszatáj”. He writes poetry, criticism, and translates from Ex-Yugoslavian languages. His research focuses on Hungarian and exYugoslav literary contacts. 
He has published 4 books of poems, his works are translated into Czech, English, French, Croatian, Greek, Romanian, Slovenian, Spanish, and Serbian languages.

Roland Orcsik se je rodil v vojvodinskem mestu Bečej/Óbecse, od leta 1992 pa živi na Madžarskem, v Szegedu, je pesnik, esejist, kritik in prevajalec. Je eden urednikov revije Tiszatáj in adjunkt na szegedski slavistki, prejemnik številnih literarnih nagrad. $\vee$ madžarščini je izdal štri pesniške zbirke, roman in razpravo o južnoslovanskih vplivih na literarno delo Istvána Domonkosa. Prevaja tudi iz slovenščine, knjižno sta izšla njegova prevoda poezije Aleša Štegra in Primoža Čučnika.

Marcello Potocco is a poet, translator and an assistant professor at the University of Primorska. He has published essays and articles in the journals and publications, such as Primerjalna književnost, CICWeb Journal etc. He has published his book-length study National imaginary, literary imaginary (2012) and has issued five poetry collections. He appeared in festivals in Slovenia and abroad, while his poetry has been translated into English, Italian, Hebrew, Czech, Croatian, Macedonian, Turkish etc.

Marcello Potocco je pesnik, prevajalec in docent za književnost na Univerzi na Primorskem. Objavljal je v publikacijah Primerjalna književnost, CLCweb idr. Izdal je znanstveno monografijo Nacionalni imaginariji, literarni imaginariji (2012) ter pet pesniških zbirk. Nastopal je na festivalih doma in $\vee$ tujini, njegova poezija pa je prevedena $\vee$ številne tuje jezike (angleščina, italijanščina, hebrejščina, češčina, turščina itn.). $\checkmark$ slovenščino je prevedel več knjig, mdr. Barneyjevo verzijo Mordecaija Richlerja.

Irma Ratiani is a Georgian literary scholar, editor and translator, professor at Tbilisi State University and director of Rustaveli Institute of Georgian Literature.The major field of her research includes literary theory, general and comparative literary studies, analysis of genres etc. She is an author an editor of several monographs and textbooks, as well as more than 80 articles and contributions. She was awarded the Grigol Kiknadze Scientific Award the Order of Presidential Excellence of Georgia.

Irma Ratiani je gruzijska literarna zgodovinarka, urednica in prevajalka, profesorica na Državni unverzi v Tbilisiju in predstojnica Inštuta Rustaveli za gruzijsko literaturo. Njene raziskave se osredinjajo na literarno teorijo, splošno in primerjalno književnost, analizo žanrov ipd. Je avtorica in urednica številnih monografij in učbenikov, pa tudi več 
kot 8o člankov. Nagrajena je bila s Znanstveno nagrado Grigola Kiknadzeja ter z Redom za zasluge gruzijskega predsednika.

Janez Strehovec is professor of new media art theory and director of Institute of New Media Art and Electronic Literature, Ljuf bljana. He authored eight scientific monographs, the most recent being Text as Ride (2016). His English essays are included as book chapters and published in scientific journals, such as Digital Creativity, CLC Web, CTheory, Journal of Popular Culture, Afterimage, Cybertext Yearbook, Electronic Book Review, Cultura, Technoetic Arts, First Monday, Teksty Drugie etc.

Janez Strehovec je direktor Inštituta za nove medije in elektronsko literaturo, Ljubljana. Je avtor osmih monografij, zadnja izmed njih je Text as Ride (2016). Njegovi angleški eseji so vključeni kot pogi lavja $\vee$ monografijah in objavljeni $\vee$ številnih znanstvenih revijah, kot so Digital Creativity, CLC Web, CTheory, Journal of Popular Culture, Afterimage, Cybertext Yearbook, Electronic Book Review, Cultura, Technoetic Arts, First Monday, Teksty Drugie idr.

Andrei Terian is professor of Romanian literature at the University of Sibiu and a senior researcher with the Institute of Literary History and Theory of the Romanian Academy. His research focuses on contemporary Romanian literature, cultural theory, the history of modern criticism, comparative and world literature. He has published essays and papers in Romania and abroad. His works include two monographs and co-authorship in reference series on Romanian and world literature.

Andrei Terian je profesor romunske literature na Univerzi v Sibiu in znanstveni svetnik na Inštitutu za literarno zgodovino in teorijo pri romunski Akademiji. Raziskovalno se osredinja na sodobno romunsko književnost, kulturno teorijo, zgodovino sodobnega kritištva ter svetovno književnost. Objavil je številne članke in prispevke tako $v$ Romuniji kot $v$ tujini. Je avtor dveh monografij in soavtor referenčnih literarnozgodovinskih zbirk o romunkski in svetovni književnosti.

Tomaž Toporišič is a dramaturge and theatre theoretician. He is Associate Professor at the University of Ljubljana. He is author of several books and readers including The Vulnerable Body of Text and Stage and Occupying Spaces: Experimental Theatre in Central Europe. His essays include The new Slovene Theatre and Italian Futurism (2014), (Re)staging the Rhetorics of Space (2014) and Deconstructive Readings of the Avant-garde Tradition in Post-socialist Retro-avant-garde Theatre (Aesthetics of Matter, 2013). 
Tomaž Toporišič je dramaturg in gledališki teoretik, izredni profesor za področje dramaturgije in scenskih umetnosti na AGRFT Univerze $v$ Ljubljani, kot gostujoči predavatelj pa sodeluje tudi na Filozofski fakulteti UL. Je avtor številnih razprav in znanstvenih monografij. Njegova primarna področja raziskovanja so teorija in zgodovina uprizoritvenih praks in literature, predvsem interakcije med obema področjema; semiotika kulture in kulturne študije. Za svoje delo je prejel več nagrad.

Gašper Troha se ukvarja s sociologijo literature ter sodobne svetovne in slovenske dramatike in gledališča. Predava na Filozofski fakulteti, bil je programski vodja festivala Vilenica (2010-2013) in generalni direktor Direktorata za ustvarjalnost na MK RS Objavljal je $\checkmark$ številnih domačih in tujih znanstvenih revijah. $V$ letu 2015 je izdal monografijo Ujetniki svobode o razvoju slovenske dramatike in gledališča pod socializmom bil pa je tudi urednik in soavtor številnih monografij

Gašper Troha focuses his research on the sociology of literature, as well as on questions of contemporary theatre. He works at the Faculty of Arts (Univ. of Ljubljana) and heads the Arsem Publishing House. He was the programme director of the Vilenica Festival (2010-2013). He has published a monograph Prisoners of Freedom (AGRFT, Ljubljana) contributed to numerous journals, and edited several monographs with foreign publishers.

Jonatan Vinkler is associate professor at the University of Primorska. During the years 2000 and 2006 he worked as editor at Nova revija Publishing House. From 2002 to present he collaborates in editing and from 2009 he is editor-in-chief of the Collected works of Primož Trubar. He has taken part on conferences esp. in Czech Republic. From 2010 he is editor-in-chief of the University of Primorska Press. His research focuses on Czech-Slovenian relations, cultural history and reformation in literature.

Jonatan Vinkler je izredni profesor na Univerzi na Primorskem. Od 2000 do 2006 je bil urednik na založbi Nova revija, od 2002 sodeluje pri Zbranih delih Primoža Trubarja, od leta 2009 pa je glavni urednik te zbirke. Udeležil se je uglednih znanstvenih konferenc, zlasti na Češkem. Od leta 2010 je glavni urednik Založbe Univerze na Primorskem. Njegovo raziskovalno delo se osredotoča na češko-slovenske stike, kulturno zgodovino in še zlasti na reformacijo v slovenski literaturi.

Špela Virant, PhD, is an Associate Proffessor in German literature at the Faculty of Arts, University of Ljubljana. She studied 
comparative, German and English literature. Her research focuses on modern German literature, theory and history of drama, intercultural literary studies, and ethical criticism. She published a monograph, Redramatisierter Eros: zur Dramatik der 1990er Jahre, and is co-editing the journal Ars \& Humanitas.

Špela Virant je izredna profesorica za književnosti $\vee$ nemškem jeziku na Filozofski fakulteti Univerze v Ljubljani. Študirala je primerjalno književnost, nemščino in angleščino. Njena raziskovalna področja so sodobna nemška književnost, teorija in zgodovina drame, medkulturne literarnovedne študije, etika in literatura. Objavila je monografijo Redramatisierter Eros: zur Dramatik der 199oer Jahre in je sourednica revije Ars \& Humanitas. 



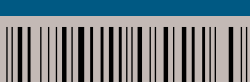

